\title{
ANALISIS DISKRIMINAN UNTUK MENGELOMPOKAN KEMAMPUAN SISWA BERDASARKAN NILAI PENGETAHUAN AGAMA DAN PENGETAHUAN UMUM
}

\author{
Khairul Umam ${ }^{1}$, Suryawati ${ }^{2}$ \\ ${ }^{12}$ Department of mathematic Education, Syiah Kuala University
}

E-mail: Khumam77@yahoo.com

Diterima: 05/08/2019; Disetujui: 25/08/2019

\begin{abstract}
ABSTRAK
Penelitian ini merupakan penelitian tentang pengelompokan kemampuan siswa berdasarkan nilai pengetahuan agama dan pengetahuan umum. Pengumpulan data dilakukan dengan cara mengumpulkan nilai siswa di Sekolah Dasar dari beberapa kelas. Data mentah yang telah dikumpulkan terlebih dahulu dinormalkan menggunakan skala kemudian dianalisis menggunakan discriminan fisher melalui aplikasi SPSS. Variabel dependen dalam penelitan ini adalah pengelompokan kemampuan siswa tingkat sekolah dasar, sedangkan variabel independen terdapat 10 faktor yang dapat mempengaruhi kemampuan siswa dalam pengetahuan agama dan pengetahuan umum. Hasil yang diperoleh dalam peneitian ini dari 100 sampel bahwa masih ada siswa yang nilai kemampuan agamanya lebih rendah dari nilai pengetahuan umum. Fungsi diskriminan fisher yang terbentuk adalah: $0,069 \mathrm{x}_{1}+(-$ $0,236) \mathrm{x}_{2}+(-0,849) \mathrm{x}_{3}+1,314 \mathrm{x}_{4}+1,862 \mathrm{x}_{5}+0,804 \mathrm{x}_{6}+0,021 \mathrm{x}_{7}+0,555 \mathrm{x}_{8}+0,994 \mathrm{x}_{9}+$ $0,721 \mathrm{x}_{10}=0$ dan $0,039 \mathrm{x}_{1}+(-0,322) \mathrm{x}_{2}+(-0,213) \mathrm{x}_{3}+1,277 \mathrm{x}_{4}+1,308 \mathrm{x}_{5}+1,223 \mathrm{x}_{6}+(-$ $0,242) \mathrm{x}_{7}+0,817 \mathrm{x}_{8}+0,838 \mathrm{x}_{9}+0,744 \mathrm{x}_{10}=0$
\end{abstract}

Kata Kunci: Kemampuan Siswa, Pengetahuan agama dan umum, Discriminan Fisher. 


\begin{abstract}
This study is a study of the grouping of students' ability based on the value of religious knowledge and general knowledge. Data collection is done by collecting student grades in elementary schools from several classes. The raw data that has been collected first normalized using Ln is then analyzed using discriminant fisher through SPSS application. The dependent variable in this research is the clustering of students 'ability at the elementary level, while the independent variables are 10 factors that can affect students' ability in religious knowledge and general knowledge. The results obtained in this study of 100 samples that there are still students whose religious proficiency value is lower than the value of general knowledge. The function of the fisher discriminant formed are:0,069 $x_{1}+(-0,236) x_{2}+(-0,849) x_{3}+1,314 x_{4}+1,862 x_{5}+$ $0,804 x_{6}+0,021 x_{7}+0,555 x_{8}+0,994 x_{9}+0,721 x_{10}=0$ and $0,039 x_{1}+(-0,322) x_{2}+(-0,213) x_{3}+$ $1,277 x_{4}+1,308 x_{5}+1,223 x_{6}+(-0,242) x_{7}+0,817 x_{8}+0,838 x_{9}+0,744 x_{10}=0$.
\end{abstract}

Keywords: Student Ability, Religious and General Knowledge, Discriminan Fisher. 


\section{PENDAHULUAN}

Analisis diskriminan merupakan model yang ditandai dengan adanya variabel dependen yang berupa data kategori dan data independen berupa data non kategori. Variabel dependen dalam penelitian ini adalah kategori nilai pengetahuan umum dan nilai pengetahuan agama. Sedangkan variabel independennya yaitu nilai fiqh, qur'an hadits, aqidah akhlaq, ski, bahasa arab, ppkn, bahasa Indonesia, matematika, ipa, dan ips. Dengan demikian, hasil yang ingin diketahui bergantung kepada data-data independen. Salah satu tujuan analisis ini adalah untuk mengelompokkan kemampun siswa berdasarkan nilai pengetahuan agama dan nilai pengetahuan umum.

Melihat kondisi siswa yang moralnya semakin lemah menjadikan penyebab utama yang membuat peneliti harus menganalisis apakah moral siswa bergantung kepada nilai pengetahuan umum dan agamanya.

\section{LANDASAN TEORI}

Analisis Diskriminan adalah teknik Multivariat yang termasuk pada Dependence Method, dengan ciri adanya variabel dependen dan independen. Dengan demikian, ada variabel yang hasilnya tergantung pada data variabel independen. Model Analisis Diskriminan ditandai dengan ciri khusus yaitu data variabel dependen yang harus berupa data kategori, sedangkan data independen justru berupa data non kategori.

Analisis diskriminan yang dilakukan oleh penelti menggunakan metode fisher. Prinsip utama dari fungsi diskriminan fisher adalah pemisahan sebuah populasi. Fungsi diskriminan yang terbentuk dapat digunakan untuk pengelompokan suatu
Analisis Diskriminan Untuk Mengelompokan Kemampuan Siswa Berdasarkan Nilai Pengetahuan Agama Dan Pengetahuan Umum Khairul Umam, Suryawati.

observasi berdasarkan kelompok-kelompok tertentu (Operator, 15 desember 2017).

Pengelompokan responden kedalam grup 1 atau grup 2, dalam pembahasan kali ini yaitu kedalam grup obesitas atau kedalam grup tidak obesitas dapat dilakukan secara manual maupun dengan program SPSS. Secara manual tanpa cutting score pun, kita dapat langsung memprediksi grup setiap responden yaitu dengan melihat paling dekat ke centroid mana skor diskriminan masing-masing objek. Misalnya, skor diskriminan responden 1 sampel analisis, yang sebesar 2,18646, tentunya lebih dekat ke 1,787 (centroid grup 1) daripada ke1,564 (centroid grup 2. Oleh karena itu responden 1 diprediksi masuk ke grup 1. Responden 15 sampel analisis, dengan skor diskriminan $-0,27107$, tentunya masuk grup 2.(Simamora,18 desember 2017). Sedangkan secara program SPSS memberikan peluang masuk ke dalam grup 1 dan grup 2, dimana peluang paling besar ke dalam grup mana yang dimiliki suatu objek, ke dalam grup itulah objek tersebut kita prediksi. Responden 1 sampel analisis, misalnya 26 memiliki peluang ke dalam grup 1 sebesar 0,99904 dan ke dalam grup 2 sebesar 0,00096. Tentunya, peluang ke dalam grup 1 lebih besar, jadi ke dalam grup itulah responden 1 diprediksi. (Simamora, 2005:166).

Setiap data baru (indikator) yang dimasukkan terhadap salah satu fungsi $\mathrm{Y}\left(\mathrm{f}_{(\mathrm{x})}\right)$ akan diperoleh hasil berbentuk nilai. Nilai dari masing-masing fungsi $\mathrm{Y}\left(\mathrm{f}_{(\mathrm{x})}\right)$ tersebut berbeda, fungsi $\mathrm{Y}\left(\mathrm{f}_{(\mathrm{x})}\right)$ akan dipilih (dikategorikan) adalah fungsi $\mathrm{Y}\left(\mathrm{f}_{(\mathrm{x})}\right)$ yang menghasilkan nilai paling tinggi. 
Kathleen dan Carmen (2002) berpendapat setiap fungsi $\mathrm{Y}\left(\mathrm{f}_{(\mathrm{x})}\right)$ dalam proses SPSS terdiri dari variabel $\mathrm{X}_{p}$ (indikator) untuk satu fungsi klasifikasi bagi satu kelompok. Variabel dalam fungsi diskriminan linier Fisher ini boleh digunakan secara terus untuk pengklasifikasian atau pengelompokkan terhadap data baru.Variabel-variabel tersebut diperoleh bagi setiap kelompok dan dari sebarang kasus baru yang diinput dan diproses, hasilnya dikelompokkan ke dalam kelompok yang nilai diskriminannya $\mathrm{Y}\left(\mathrm{f}_{(\mathrm{x})}\right)$ lebih tinggi.

Ilmu pengetahuan merupakan rangkaian kata yang sangat berbeda namun memiliki kaitanyangsangat kuat. Ilmu dan pengetahuan memang terkadang sulit dibedakan oleh sebagian orang karena memiliki makna yang berkaitan dan sangat berhubungan erat. Membicarakan masalah ilmu pengetahuan dan definisinya memang sebenarnya tidak semudah yang diperkirakan. Adanya berbagai definisi tentang ilmu pengetahuan ternyata belum dapat menolong untuk memahami hakikat ilmu pengetahuan itu.

Didalam kamus Bahasa Indonesia, ilmu merupakan pengetahuan tentang suatu bidang yang disusun secara bersistem menurut metode tertentu yang dapat digunakan untuk menerangkan gejala-gejala tertentu tersebut. Mulyadhi Kartanegara mengatakan ilmu adalah any organized knowledge. Ilmu dan sains menurutnya tidakberbeda, terutama sebelum abad ke-19, tetapi setelah itu sains lebih terbatas pada bidang-bidang fisika tau inderawi, sedangkanilmu melampauinya pada bidang-bidangnon fisik seperti metafisika.
Adapun beberapa definisi ilmu menurut para ahli seperti yang dikutip oleh Bakhtiar tahun 2005 diantaranya adalah:

a. Mohamad Hatta, mendefinisikan ilmu adalah pengetahuan yang teratur tentang pekerjaan hukum kausal dalam suatu golongan masalah yang sama tabiatnya maupun itu menurut kedudukannya tampak dari luar, maupun menurut bangunannya dari dalam.

b. Ralph Ross dan Ernest Van Den Haag, mengatakan ilmu adalah yang empiris, rasional, umum dan sistematik dan ke empatnya serentak.

c. Karl Pearson, mengatakan ilmu adalah lukisan atau keterangan yang komprehensif dan konsisten tentang fakta pengalaman dengan istilah yang sederhana.

d.Ashley Montagu, menyimpulkan bahwa ilmu adalah pengetahuan yang disusun dalam satu sistem yang berasal dari pengamatan, studi dan percobaan untuk menentukan hakikat prinsip tentang hal yang sedang dikaji.

Dari beberapa definisi ilmu yang dijelaskan para ahli di atas dapat disimpulkan bahwa ilmu merupakan pengetahuan yang rasional, sistematik, konfrehensif, konsisten, dan bersifat umum tentang fakta dari pengamatan yang telah dilakukan. Agama dan pengetahuan umum tidak selamanya berada dalam pertentangan dan ketidaksesuaian. Banyak ilmuan yangn berusaha mencarihubungan antara keduanya. Pengetahuan umum dan agama merupakan dua entitas yang berbeda, namun keduanyasama-sama memiliki peranan sangat penting dalam kehidupan manusia. Agama merupakan petunjuk yang dipedomankan melalui aturan dalam kitab suci sedangkan ilmu pengetahuan umum berpijak pada interaksi serta komunikasi yang 
terbangun dalam masyarakat. Keduanya akan bergandeng pada proses prilaku, moral, etika, strata fikasi sosial dan struktur masyarakat

Variabel dependen dalam penelitian ini adalah kemampuan siswa berdasarkan nilai pengetahuan agama dan nilai pengetahuan umum. Sedangkan variabel independen dalam penelitian ini adalahX1 (Alquran Hadist); X2 (Fiqih); X3(Aqidah Akhlak); X4 (Sejarah Kebudayaan Islam); X5 (Bahasa Arab); X6 (Ppkn); X7 (Bahasa Indonesia); X8 (Matematika); X9 (IPA); dan X10 (IPS).

\section{METODE PENELITIAN}

Jenis penelitian ini menggunakan deskriptif kuantitatif. Sedangkan dalam mengumpulkan data dari studi literatur. Populasi dalam penelitian ini adalah siswa dari SD Negeri Lamnga. Sampel yang diambil dalam penelitian ini sebanyak 100 siswa. Penelitian ini menggunakan sumber data primer yaitu data yang diperoleh secara langsung dari sekolah. Data berupa nilai siswa dari nilai raport. Teknik pengumpulan data dalam penelitian ini dengan menggunakan observasi nilai raport siswa yang diperoleh dari sekolah dasar sesuai variabel independen yang diperlukan.

\section{HASIL PENELITIAN DAN PEMBAHASAN}

Data yang telah didapat oleh Peneliti yang bersumber dari nilai rapor 100 siswa merupakan data mentah yang variannya jauh berbeda. Oleh karenanya, data tersebut harus diubah menjadi normal terlebih dahulu, sehingga varian dari masingmasing variabel karakteristik umum yang menentukan tingkat obesitas di dalam data tersebut menjadi homogen.
Analisis Diskriminan Untuk Mengelompokan Kemampuan Siswa Berdasarkan Nilai Pengetahuan Agama Dan Pengetahuan Umum Khairul Umam, Suryawati.

Berikut adalah data variabel independen yang menentukan tingkat kemampuan siswa berdasarkan ilmu pengetahuan agama dan ilmu pengetahuan umum (Alquran hadist, Fiqih, Aqidah akhlak, Sejarah kebudayaan islam, Bahasa arab, Bahasa indonesia, Matematika, IPA, dan IPS) yang telah ditabulasikan (lihat Tabel 1)

\section{Tabel 1. Data Real}

\begin{tabular}{|c|c|c|c|c|c|c|c|c|c|c|c|}
\hline \multirow{2}{*}{ so } & \multirow{2}{*}{ NAMA } & \multicolumn{5}{|c|}{ MATA PELAJARAN AGAIIA } & \multicolumn{5}{|c|}{ MATA PELAJARAN LMITM } \\
\hline & & OrHd & Fiq & $\mathrm{Aq} / \mathrm{Ak}$ & SKI & B.Arb & PPKn & B.Ind & Nat & IPA & IPS \\
\hline 1 & NISAUL KHAIRANI & 86 & 78 & 78 & 70 & 80 & 70 & 78 & 82 & 90 & 90 \\
\hline 2 & KHALIL EDRIA & 83 & 75 & 79 & 80 & 70 & 76 & 78 & 82 & 90 & 90 \\
\hline 3 & NAJWA ULHUSNA & 83 & 74 & 73 & 90 & 80 & 79 & 85 & 80 & 69 & 77 \\
\hline 4 & PUIRINAILATUL IZZAH & 83 & 71 & 72 & 60 & 70 & 82 & 70 & 75 & 74 & 68 \\
\hline 5 & MFAIZ ALAMUL HUDA & 73 & 72 & 75 & 60 & 70 & 78 & 74 & 80 & 70 & 75 \\
\hline 6 & NANDA FITRIANI & 76 & 72 & 70 & 80 & 80 & 86 & 68 & 64 & 68 & 79 \\
\hline 7 & DAMAN HURI BASYR & 65 & 68 & 66 & 60 & 60 & 84 & 73 & 67 & 75 & 77 \\
\hline 8 & NURUL ILMI & 68 & 75 & 68 & 90 & 60 & 75 & 75 & 68 & 68 & 73 \\
\hline 9 & NABLA JS & 72 & 68 & 68 & 65 & 60 & 74 & 67 & 66 & 72 & 75 \\
\hline 10 & HANIF RAMADHAN & 68 & 73 & 66 & 60 & 60 & 76 & 68 & 83 & 68 & 68 \\
\hline 11 & PUTRIBALQIS & 79 & 71 & 70 & 70 & 70 & 67 & 67 & 62 & 68 & 73 \\
\hline 12 & SAIDUL ARIF & 77 & 67 & 67 & 70 & 60 & 78 & 67 & 63 & 72 & 66 \\
\hline 13 & ZAKIMULTAZAM & 66 & 67 & 68 & 65 & 60 & 77 & 73 & 63 & 68 & 73 \\
\hline 14 & IHSANMOULANA & 77 & 68 & 69 & 60 & 90 & 66 & 67 & 68 & 72 & 68 \\
\hline 15 & TASYA FAHIRA & 71 & 64 & 65 & 70 & 70 & 70 & 67 & 66 & 72 & 72 \\
\hline 16 & NURFARI & 70 & 66 & 68 & 70 & 70 & 63 & 75 & 66 & 68 & 69 \\
\hline 17 & MZARKASYIAL-AFKAR & 67 & 67 & 66 & 70 & 70 & 71 & 67 & 67 & 72 & 66 \\
\hline 18 & SYIFA ZAKIYA & 68 & 65 & 64 & 60 & 70 & 75 & 67 & 66 & 78 & 65 \\
\hline
\end{tabular}

\begin{tabular}{|c|c|c|c|c|c|c|c|c|c|c|c|}
\hline 19 & | MLMTATAZUL. FIKRI & 61 & 62 & 62 & 60 & 60 & 67 & 67 & 65 & 68 & 62 \\
\hline 20 & MLHAMMAD FAYYADH DESFA & 92 & 98 & 97 & 20 & 80 & 98 & क7 & 88 & 93 & 90 \\
\hline 21 & IRZA MALLIDIA & 88 & 95 & 93 & 80 & 80 & 91 & 92 & 84 & 89 & \\
\hline 22 & DALILA KHAIRIA & 80 & 83 & 85 & 20 & 80 & 90 & 90 & 81 & 87 & 84 \\
\hline 23 & ALEA MALLLEA & 80 & 86 & 91 & 65 & 60 & 81 & 90 & 77 & 90 & 79 \\
\hline 24 & \begin{tabular}{|l|l|} 
MILA ISLAMII \\
\end{tabular} & 78 & 90 & 88 & 65 & 65 & 73 & 94 & 77 & 91 & \\
\hline 25 & MLHAMMAN AHRAR & 81 & 80 & 87 & 20 & 70 & 80 & 89 & 79 & 85 & 77 \\
\hline 26 & AFLA XALLDA & 83 & 77 & 88 & 70 & 65 & 80 & 89 & 81 & 75 & 72 \\
\hline 27 & NAZZRA ARDENA & 78 & 76 & 74 & 20 & 70 & 72 & 75 & 73 & 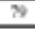 & 73 \\
\hline $2 \mathrm{R}$ & MITTAHLZ AZIS SAPUTRA & 70 & 71 & 69 & 20 & 70 & 70 & 72 & 85 & 78 & \\
\hline 29 & AIMAD 'ARIFLDDIN & 74 & 71 & 74 & 60 & 70 & 75 & 93 & 70 & 72 & 7 \\
\hline 30 & MLHAMMAD ALFI NAWADIR & 78 & 68 & 64 & 20 & 65 & 70 & 50 & 70 & 83 & 7 \\
\hline 31 & TLARA & 65 & \begin{tabular}{|c|}
63 \\
\end{tabular} & 61 & 75 & 70 & 70 & 90 & 68 & 83 & \\
\hline 32 & WILDATHCLL SAVITRA & 66 & 62 & 62 & 60 & 70 & 69 & 70 & 75 & 77 & \\
\hline 33 & IAMALILL MALIDI & 65 & 69 & 65 & 60 & 60 & 68 & 90 & 71 & 70 & \\
\hline 34 & NAILA MASRLRA & 65 & 64 & 67 & 60 & 60 & 70 & 70 & 67 & 75 & 68 \\
\hline 35 & NABHL.A ARDDEA & 64 & 62 & 62 & 65 & 60 & 69 & 50 & 68 & $\eta 7$ & \\
\hline 36 & M.HADI & 65 & 64 & 62 & 60 & 65 & 69 & 70 & 66 & 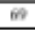 & \\
\hline 37 & MLLAAMMAD IKBML. & 63 & 62 & 62 & 60 & 60 & 70 & 90 & 68 & 70 & \\
\hline $3 \mathrm{~B}$ & FADUUZZZABARI & 62 & \begin{tabular}{|l|}
61 \\
\end{tabular} & 61 & 60 & 70 & 70 & 73 & 68 & 70 & \\
\hline 39 & NLDULL MLIRZIQAH & 66 & 62 & 62 & 60 & 60 & 68 & 68 & 65 & 66 & \\
\hline 40 & M.EARIELNA & 61 & \begin{tabular}{|l|}
61 \\
\end{tabular} & 63 & 60 & 60 & 66 & 68 & 65 & 66 & \\
\hline 41 & MLFTAHL_OHALRA & 63 & \begin{tabular}{|c|}
63 \\
\end{tabular} & 63 & 60 & 60 & 68 & 66 & 67 & 66 & \\
\hline 42 & RIF ML. AL. HAFIT & 59 & 50 & 60 & 60 & 60 & 66 & 66 & 63 & 65 & \\
\hline 43 & SUIIIILL RISKI & 62 & 59 & 59 & 60 & 70 & 66 & 66 & 64 & 66 & \\
\hline 44 & MZZA LL KAMAL & 66 & \begin{tabular}{|l|}
61 \\
\end{tabular} & 68 & 20 & 60 & 67 & 70 & 59 & 68 & \\
\hline 45 & IRAYANA AMALLA & 72 & 74 & 68 & 65 & 60 & 65 & 67 & 60 & 62 & \\
\hline 46 & RAISLI. ANKAR & 62 & \begin{tabular}{|l|l}
63 \\
\end{tabular} & 69 & $N$ & 60 & 75 & 69 & 63 & 72 & \\
\hline 47 & \begin{tabular}{|l|l|} 
R.SKLI IHAMI \\
\end{tabular} & 84 & 65 & 66 & 80 & 60 & 64 & 69 & 60 & 7 & \\
\hline $4 \mathrm{R}$ & RAFMAT RIZAKII & 73 & 6 & 62 & 65 & 65 & 64 & 66 & 72 & 65 & 6 \\
\hline 49 & ADE MEBRTA & 66 & 60 & 57 & 20 & 60 & 62 & 65 & 61 & 65 & \\
\hline 50 & FUTRI AMEI & 81 & 76 & 72 & 80 & 70 & 70 & 77 & 71 & 77 & \\
\hline 51 & PITRI RALIZAH & 79 & 72 & 70 & 20 & 70 & 69 & 73 & 65 & 73 & \\
\hline 52 & NISAUL KAMALI & 65 & \begin{tabular}{|l|}
81 \\
\end{tabular} & 77 & 80 & 70 & 70 & 90 & 66 & 62 & \\
\hline 53 & IZZLL KAMILA & 91 & 84 & 75 & 85 & 70 & 78 & 82 & 79 & 83 & \\
\hline 54 & ZARQAA SALSABLA & $n$ & 6i] & 64 & 20 & 60 & 63 & 61 & 59 & 60 & \\
\hline 55 & M. K.AHLIL GLARAN & 74 & 65 & 68 & 65 & 60 & 64 & 69 & 60 & 64 & \\
\hline 56 & RLANUTR SALSAIILA & 66 & 66 & 65 & 65 & 60 & 64 & $\pi$ & 60 & 65 & \\
\hline 57 & BARRAM AL-AIMI & 78 & 73 & 65 & 60 & 60 & 70 & 76 & 67 & 76 & \\
\hline 58 & NLLULL HANISA & 74 & 73 & 67 & 20 & 70 & 74 & 72 & 67 & 67 & \\
\hline 59 & M.RAYYANRAMADHAK & 79 & 78 & 62 & 85 & 70 & 67 & 70 & 59 & 70 & \\
\hline 60 & ANNISA RAMADILANI & 83 & 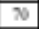 & 71 & 80 & 70 & 76 & $\pi 7$ & 65 & 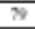 & \\
\hline
\end{tabular}




\begin{tabular}{|c|c|c|c|c|c|c|c|c|c|}
\hline 63 LIZZA ANANDA & 83 & & & & 10 & 1. & & & \begin{tabular}{l|l}
9 & 76 \\
\end{tabular} \\
\hline \begin{tabular}{l|l}
64 & TUTIA RAEM \\
\end{tabular} & 67 & 81 & 67 & 77 & 73 & 75 & 82 & & \\
\hline \begin{tabular}{l|l}
65 & MORSTIDNN \\
\end{tabular} & 75 & 75 & 70 & 84 & 70 & 72 & 80 & 67 & \\
\hline \begin{tabular}{l|l}
66 & ZAKIA UNNISA
\end{tabular} & 69 & 12 & 72 & 88 & 75 & 70 & 75 & & \\
\hline \begin{tabular}{l|l}
67 & HUSNUL AUZA \\
\end{tabular} & 70 & 74 & 67 & 69 & 65 & 72 & & & \\
\hline 68 AKNALL MOTAWAKIL & 62 & 82 & 64 & 85 & 70 & 69 & 70 & \begin{tabular}{l|l}
67 & 6 \\
\end{tabular} & 68 \\
\hline \begin{tabular}{l|l}
69 & HAFID ZAIRU
\end{tabular} & 66 & 78 & 67 & 77 & 65 & 70 & 69 & & \\
\hline \begin{tabular}{l|l}
70 & NMNOKSALMNAN
\end{tabular} & 63 & 65 & 63 & 73 & 65 & 75 & 73 & 707. & $\begin{array}{ll}7469 \\
69\end{array}$ \\
\hline 71 AIBBARMATLANA & 60 & 67 & 60 & 72 & 60 & 72 & 74 & 68 & \begin{tabular}{l|l}
70 & 70 \\
\end{tabular} \\
\hline 72 GLNTURNALLIKILAKB,AR & 67 & 67 & 60 & 80 & 60 & 69 & 68 & & \\
\hline $\begin{array}{ll}73 & \text { SYARURMONIAZ }\end{array}$ & 60 & 60 & 60 & 71 & 60 & 68 & 68 & & \\
\hline 74 CHALD AL MARMOR & 60 & 65 & $6 !$ & 62 & 60 & 69 & 70 & \begin{tabular}{l|l}
67 & 6 \\
\end{tabular} & \\
\hline $\begin{array}{ll}75 & \text { MaAMGGA ADRIAN } \\
\end{array}$ & 60 & 62 & 60 & 69 & 65 & 68 & 68 & \begin{tabular}{l|l}
4 & 6
\end{tabular} & $\begin{array}{ll}66 & 67 \\
\end{array}$ \\
\hline 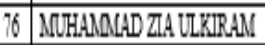 & 60 & 61 & 60 & 62 & 60 & 68 & 70 & 656. & 6968 \\
\hline 77 MHARAL MAODZLA & 60 & 60 & 60 & 65 & 60 & 69 & 68 & $\begin{array}{l}656 \\
65\end{array}$ & $\begin{array}{ll}66 & 67 \\
\end{array}$ \\
\hline 78 MAATALUL IHSAN & 60 & 62 & 60 & 60 & 60 & 68 & 69 & $\begin{array}{ll}656 \\
\end{array}$ & 6768 \\
\hline 79 LAILATIL AMALIA & $6 !$ & 62 & 60 & $6 !$ & 60 & 67 & 67 & & 676 \\
\hline \begin{tabular}{l|l}
80 & FARAH AZZIIA
\end{tabular} & 95 & 9.4 & 9 & 82 & 75 & 90 & 93 & 819 & \begin{tabular}{l|l}
928 & 88 \\
2
\end{tabular} \\
\hline \begin{tabular}{|l|l|}
81 & RANORADELIA \\
\end{tabular} & 90 & 9.5 & 95 & 90 & 75 & 86 & 90 & 798. & $\begin{array}{ll}84 & 83 \\
\end{array}$ \\
\hline \begin{tabular}{c|l|l}
82 & YURRA INDA ZULMNAN
\end{tabular} & 90 & 87 & 95 & 87 & 80 & 83 & 82 & 778 & 8282 \\
\hline $\begin{array}{ll}83 & \text { DINA } \\
\end{array}$ & 79 & 79 & 84 & 78 & 70 & 72 & 76 & 68 & \begin{tabular}{l|l}
76 & 73 \\
\end{tabular} \\
\hline \begin{tabular}{l|l}
84 & SITIRAHCALLA \\
\end{tabular} & 80 & 88 & 87 & 82 & 80 & 70 & 72 & 67 & 72 \\
\hline \begin{tabular}{l|l|}
85 & ANIAS SAPUTRA \\
\end{tabular} & 74 & 76 & 84 & 78 & 65 & 67 & 69 & $\theta 4$ & $\begin{array}{ll}72 & 67 \\
\end{array}$ \\
\hline \begin{tabular}{l|l}
86 & RSSKI \\
\end{tabular} & 82 & 80 & 80 & 75 & 70 & 67 & 66 & & $\begin{array}{ll}66 & 67 \\
6\end{array}$ \\
\hline \begin{tabular}{l|l}
87 & TATL ABRAR \\
\end{tabular} & 80 & 61 & 82 & 73 & 65 & 68 & 68 & 65 & 7267 \\
\hline $\begin{array}{lll}8 & \text { ARIEL SADUTRA }\end{array}$ & 69 & $m$ & 72 & 76 & 65 & 67 & 68 & $6 ?$ & $\begin{array}{ll}71 & 67\end{array}$ \\
\hline \begin{tabular}{l|l}
9 & ZAKIA AIDAYANI \\
\end{tabular} & 64 & 79 & 70 & 63 & 60 & 69 & 71 & 68 & $\begin{array}{lll}72 & 71 \\
\end{array}$ \\
\hline \begin{tabular}{c|l}
90 & ANGGA RIZKI PRANATA \\
\end{tabular} & $7 !$ & 78 & 66 & {$[1]$} & 60 & 68 & 69 & 65 & $\begin{array}{ll}72 & 68\end{array}$ \\
\hline 91. NRAIHAN & 76 & 81 & 80 & 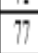 & 70 & 67 & 64 & 63 & \begin{tabular}{|l|l}
66 & 62
\end{tabular} \\
\hline 92 PUTRIANSAH & 66 & 65 & 77 & 74 & 65 & 69 & 68 & $m$ & $\begin{array}{ll}70 & 60 \\
70 & \end{array}$ \\
\hline 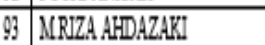 & 62 & 66 & 68 & 71 & 65 & 68 & 67 & 64 & $\begin{array}{ll}72 & 67 \\
\end{array}$ \\
\hline 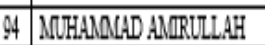 & 66 & 73 & 83 & 67 & 65 & 63 & 64 & \begin{tabular}{l|l}
4 & 6 \\
\end{tabular} & 64 \\
\hline \begin{tabular}{l|l}
$S$ & RAFAL ZU IKBAR
\end{tabular} & 69 & 76 & 66 & 63 & 65 & 65 & 65 & $\begin{array}{lll}64 & 6 \\
\end{array}$ & $\overline{66}$ \\
\hline 96 MOHALQGADRAFAL & 69 & 67 & 75 & 11. & 70 & 64 & 63 & \begin{tabular}{l|l}
63 & 6 \\
\end{tabular} & \begin{tabular}{l|l}
66 & 62 \\
\end{tabular} \\
\hline 97 RISKA & 67 & 69 & 75 & 10 & 65 & 62 & 63 & 656 & \begin{tabular}{l|l}
65 & 62 \\
\end{tabular} \\
\hline \begin{tabular}{l|l} 
OPUTERA IAREZA \\
\end{tabular} & $6 !$ & 60 & 68 & 65 & 60 & 63 & 66 & का & \begin{tabular}{l|l}
67 & 6.5 \\
\end{tabular} \\
\hline 99 TNAII & 60 & 65 & 60 & 60 & 60 & 63 & 63 & 63 & \begin{tabular}{l|l}
66 & 62 \\
\end{tabular} \\
\hline 100 PERA RAMINA & $6 !$ & & 59 & & 70 & $6 !$ & & & \\
\hline
\end{tabular}

Pada penelitian ini, Peneliti menormalkan beberapa variabel independen yang menentukan tingkat kemampuan siswa dengan membuat skala berdasarkan banyak kelas setiap variabel yang datanya bukan dalam bentuk satuan. Kemudian data yang telah dinormalkan tersebut dianalisis dengan discriminant fishers dimana grouping variable yang diambil adalah pengetahuan agama dan pengetahuan umum terhadap nilai mata pelajaran dari 100 siswa.
Tabel 2. Kemampuan Berpikir Kritis Subjek 1

\begin{tabular}{|c|c|c|c|c|c|c|c|c|c|c|c|}
\hline \multirow{2}{*}{10} & \multirow{2}{*}{ SALA } & \multicolumn{5}{|c|}{ IATA PELLJIRAN AGALIA } & \multicolumn{5}{|c|}{ MATA PELAJARAN CMIOMI } \\
\hline & & Qr Hd & Fig & dqfalk & SK & Barb & PPKn & BInd & Jat & $\mathbb{P P A} \mid$ & \\
\hline 1 & NSALL KHAIRAN" & 4 & 3 & 3 & 2 & 3 & 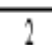 & 3 & 4 & 5 & \\
\hline 2 & BHALIL EDRA & 4 & 3 & 3 & 3 & 2 & 3 & 3 & 4 & 5 & \\
\hline 3 & NATTA ULAUSNA & 4 & 3 & 3 & j & 3 & 3 & 4 & 3 & 2 & \\
\hline 4 & PUTRINATLATUL IZZAH & 4 & 2 & 2 & 1 & 2 & 4 & 2 & 3 & 3 & \\
\hline 5 & MFAIZALAMOZ HODA & 3 & 2 & 3 & 1 & 2 & 3 & 3 & 3 & I & \\
\hline 6 & NANDA FITRANI & 3 & 2 & 2 & 3 & 3 & 4 & 2 & 1 & 2 & 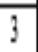 \\
\hline 1 & DAMANHIUR BASYR & 2 & 2 & 2 & t & 1 & 4 & 3 & 2 & 3 & 3 \\
\hline 8 & NURCLILMI & 2 & 3 & 2 & j & 1 & 3 & 3 & 2 & 2 & 3 \\
\hline 9 & NABZLAIS & 2 & 2 & 2 & 2 & 1 & 3 & 2 & 2 & 2 & \\
\hline 10 & HANTRAMADHAN & 2 & 3 & 2 & 1 & 1 & 3 & 2 & 4 & 2 & \\
\hline II & PUTRRB:LQIS & 3 & 2 & 2 & 2 & 2 & 2 & 2 & 1 & 2 & 2 \\
\hline 12 & SAIDULARIP & 3 & 2 & 2 & 2 & 1 & 3 & 2 & 1 & 2 & 2 \\
\hline 13 & ZAKIMOLAZAM & 2 & 2 & 2 & 2 & $!$ & 3 & 3 & $!$ & 2 & \\
\hline 14 & IBSANNOULANA & 3 & 2 & 2 & 1 & 5 & 2 & 2 & 2 & 2 & 2 \\
\hline 15 & TASYA FAFIRA & 2 & 1 & 2 & 2 & 2 & 2 & 2 & 2 & 2 & 2 \\
\hline 16 & NURARI & 2 & 2 & 2 & 2 & 2 & 1 & 3 & 2 & 2 & 2 \\
\hline 17 & NIZARRASYIALAIEKAR & 2 & 2 & 2 & 2 & 2 & 2 & 2 & 2 & 2 & \\
\hline 18 & SYIFA ZAKXYA & 2 & 2 & 1 & 1 & 2 & 3 & 2 & 2 & 3 & 2 \\
\hline 19 & MOMTAZUL FIKR & 1 & 1 & $\|$ & 1 & $!$ & 2 & 2 & 2 & 2 & 2 \\
\hline 20 & 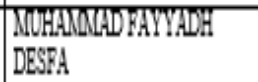 & $j$ & 6 & 6 & 2 & 3 & 6 & 6 & 4 & i & j \\
\hline 21 & IRZAMAUIDIA & 4 & 5 & 5 & 3 & 3 & 5 & 5 & 4 & 5 & 4 \\
\hline 22 & DALIA KHAIRIA & 3 & 4 & 4 & 2 & 3 & 5 & 5 & 4 & 4 & - \\
\hline 23 & AURAMAULINA & 3 & 4 & 5 & 2 & $!$ & 4 & 5 & 3 & 5 & 2 \\
\hline 24 & MMLDAISLAMI & 3 & j & 4 & 2 & 2 & 3 & 5 & 3 & 5 & 3 \\
\hline 25 & MOHALALAD,ABRAR & 4 & 3 & 4 & 2 & 2 & 3 & 5 & 3 & 4 & \\
\hline 26 & AFNAMAULIDA & 4 & 3 & 4 & 2 & 2 & 3 & 5 & 4 & 3 & 2 \\
\hline 27 & NAZRA ARDNA & 3 & 3 & 3 & 2 & 2 & 2 & 3 & 3 & 3 & 3 \\
\hline 28 & MIFTARUL AZIS SADUTRA & 2 & 2 & 2 & 2 & 2 & 2 & 2 & 4 & 3 & 3 \\
\hline 29 & AENAD 'ARITODDNN & 3 & 2 & 3 & 1 & 2 & 3 & 3 & 2 & 2 & 7 \\
\hline 30 & MOHALQAD ALFNAMATIDR & 3 & 2 & 1 & 2 & 2 & 2 & 3 & 2 & 4 & \\
\hline 31 & TIARA & 2 & 1 & 1 & $\overline{3}$ & 2 & 2 & 2 & 2 & 4 & 2 \\
\hline 32 & WILAIITULSAVITRI & 2 & 1 & 1 & 1 & 2 & 2 & 2 & 3 & 3 & 2 \\
\hline 33 & IAMLLULMAULIDI & 2 & 2 & 2 & 1 & 1 & 2 & 2 & 2 & 2 & 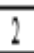 \\
\hline 34 & NAILAMASRURA & 2 & 1 & 2 & 1 & 1 & 2 & 2 & 2 & 3 & \\
\hline 35 & NABILAARDNA & 1 & 1 & 1 & 2 & 1 & 2 & 2 & 2 & 3 & \\
\hline 36 & MHADI & 2 & 1 & 1 & 1 & 2 & 2 & 2 & 2 & 2 & 2 \\
\hline 37 & MOHAMQALIIKBAL & 1 & 1 & 1 & 1 & 1 & 2 & 2 & 2 & & - \\
\hline
\end{tabular}


Jurnal Geuthèë: Penelitian Multidisiplin

Vol. 02, No. 02, (Agustus, 2019), pp. 292-300.

\begin{tabular}{|c|c|c|c|c|c|c|c|c|c|c|c|}
\hline 1 & FALIZZZLAM & 1 & 1 & 1 & 1 & 2 & 1 & 1 & 2 & 1 & \\
\hline 盟 & MLFLL MLRZLOLH & 1 & 1 & 1 & 1 & 1 & 1 & 1 & 2 & & \\
\hline 4. & MHABWLAB & 1 & 1 & 1 & 1 & 1 & 1 & 1 & 2 & 1 & 1 \\
\hline 4] & MIFTHLL LWHA & 1 & 1 & 1 & 1 & 1 & 1 & 1 & 2 & & \\
\hline 4! & RIFAL AL HAFIT & 1 & 1 & 1 & 1 & 1 & 1 & 1 & 1 & 11 & $\pi$ \\
\hline 4) & 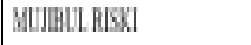 & 1 & 11 & 1 & 1 & 2 & 1 & 2 & 1 & 11 & 1 \\
\hline H & MAR LLKMAL & 1 & 1 & 1 & \begin{tabular}{|l|}
1 \\
\end{tabular} & 1 & 1 & 1 & 1 & & 1 \\
\hline 45 & DLYAN АMALL & 1 & 1 & 1 & 2 & 1 & 1 & 1 & 1 & 11 & 1 \\
\hline 4 & 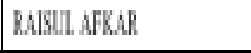 & 1 & 1 & 1 & 1 & 1 & 1 & 1 & 1 & 1 & 2 \\
\hline 47 & FISRIILHAI & 4 & 2 & 1 & 1 & 1 & 1 & 1 & 1 & 1 & 1 \\
\hline 41 & BaHLT HIRI & 1 & 1 & 1 & 1 & 1 & 1 & 1 & 2 & 1 & -1 \\
\hline 4in & ADEMERSA & 1 & 1 & 1 & 1 & 1 & 1 & 1 & 1 & 1 & 1 \\
\hline 盟 & PLTEMALL & 4 & 1 & 1 & 3 & 1 & 1 & 1 & 2 & 1 & 1 \\
\hline 5 & MTEI RALZZH & 1 & 1 & 1 & 2 & 1 & 1 & 1 & 1 & 1 & 1 \\
\hline 51 & MRAL KMALI & 1 & 4 & 1 & 1 & 1 & 1 & 1 & 2 & & 2 \\
\hline 5 & WZINGMLA & 5 & 4 & 1 & 1 & 1 & 1 & 4 & 3 & 4 & 1 \\
\hline$\$$ & 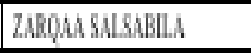 & 1 & 1 & 1 & 2 & 1 & 1 & 1 & 1 & 1 & 1 \\
\hline 59 & 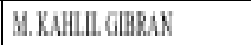 & 1 & 2 & 1 & 2 & 1 & 1 & 1 & 1 & & 1 \\
\hline 6 & BLMTRBLMALL & 1 & 2 & 1 & 2 & 1 & 1 & 1 & 1 & 11 & 1 \\
\hline$\$$ & FAHFLM AL- ANAI & 1 & 1 & 1 & 1 & 1 & 1 & 1 & 2 & 1 & 1 \\
\hline 9 & MURLL HAMIS & 1 & 1 & 1 & 2 & 1 & 1 & 1 & 2 & 1 & 1 \\
\hline 5 & MAMYMLMLDHA & 1 & 1 & 1 & 1 & 2 & 1 & 1 & 1 & & 1 \\
\hline 需 & 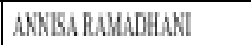 & 4 & 1 & 1 & 1 & 1 & 1 & 1 & 2 & 1 & 1 \\
\hline 6. & 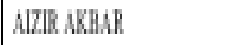 & 4 & 4 & 1 & 1 & 1 & 1 & 1 & 2 & & 1 \\
\hline 61 & MLHAMMD RUALLLARI & 4 & 4 & 1 & 2 & 1 & 1 & 1 & 4 & 1 & 1 \\
\hline 1 & LIZM WMAKDA & 4 & 4 & 1 & 1 & 1 & 1 & 1 & 2 & & 1 \\
\hline 胡 & 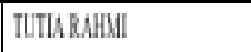 & 1 & 4 & 1 & 1 & 1 & 1 & 4 & 2 & 12 & 1 \\
\hline 62 & MLEYILIN & 1 & 1 & 1 & 4 & 1 & 1 & 1 & 1 & & 1 \\
\hline 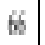 & ZMKA LMNGA & 1 & 1 & 1 & 4 & 1 & 1 & 1 & 1 & 1 & 1 \\
\hline 6. & HLSWLALAL & 1 & 1 & 1 & \begin{tabular}{|l|}
1 \\
\end{tabular} & 1 & 1 & 1 & 2 & 1 & 1 \\
\hline 61 & AMMLLMLTAWELIL & 1 & 4 & 1 & 4 & 1 & 1 & 1 & 2 & & 1 \\
\hline 褁 & \begin{tabular}{|l|l|l|l} 
& \\
\end{tabular} & 1 & 1 & 1 & 3 & 1 & 1 & 1 & 2 & 1 & 1 \\
\hline 䇛 & MMLKSLLNA & 1 & 1 & 1 & 1 & 1 & $\frac{1}{1}$ & 1 & 2 & \begin{tabular}{l|l} 
& \\
\end{tabular} & 1 \\
\hline 7l & MEMEMALLAKA & 1 & 1 & 1 & 1 & 1 & 1 & 1 & 2 & & 2 \\
\hline 71 & 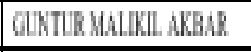 & 1 & 1 & 1 & 1 & 1 & 1 & 1 & 2 & 1 & 1 \\
\hline 71 & WAKLEMLMTA & 1 & 1 & 1 & 2 & 1 & 1 & 1 & 2 & 1 & 1 \\
\hline it & 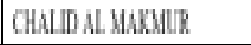 & 1 & 2 & 1 & 1 & 1 & 1 & 1 & 2 & 1 & 1 \\
\hline 73 & Makdanablan & 1 & 1 & 1 & 1 & 1 & 1 & 1 & 1 & 1 & 1 \\
\hline 7 & MLHAMMLIL LIRIRM & 1 & 1 & 1 & 1 & 1 & 1 & 1 & 2 & 1 & 1 \\
\hline 77 & MHARLAL XaLLLL & 1 & 1 & 1 & 2 & 1 & 1 & 1 & 2 & 1 & 1 \\
\hline in & MANGLIL HAS & 1 & 1 & 1 & 1 & 1 & 1 & 1 & 2 & 1 & 1 \\
\hline in & LALLATLLAMALL & 1 & 1 & 1 & 1 & 1 & 1 & 1 & 1 & 1 & 1 \\
\hline in & 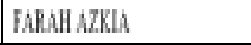 & $s$ & 5 & 6 & 4 & 1 & 5 & 1 & 4 & 3 & 4 \\
\hline B] & RLkLTALELA & 5 & 5 & 5 & 1 & 1 & 4 & $!$ & & & \\
\hline
\end{tabular}

Analisis Diskriminan Untuk Mengelompokan Kemampuan Siswa Berdasarkan Nilai Pengetahuan Agama Dan Pengetahuan Umum Khairul Umam, Suryawati.

\begin{tabular}{|c|c|c|c|c|c|c|c|c|c|c|c|}
\hline 82 & YURKA INDA ZULMINA & 5 & 4 & 5 & 4 & 3 & 4 & 4 & 3 & 4 & 4 \\
\hline 83 & DIVIA & 3 & 3 & 4 & 3 & 2 & 2 & 3 & 2 & 3 & 3 \\
\hline 84 & SITI RAHMALIA & 3 & 4 & 4 & 4 & 3 & 2 & 2 & 2 & 2 & 2 \\
\hline 85 & ANJAS SAPUTRA & 3 & 3 & 4 & 3 & 2 & 2 & 2 & 1 & 2 & 2 \\
\hline 86 & RISKI & 4 & 3 & 3 & 3 & 2 & 2 & 2 & 1 & 2 & 2 \\
\hline 87 & TAJLL ABRAR & 3 & 1 & 4 & 3 & 2 & 2 & 2 & 2 & 2 & 2 \\
\hline 88 & ARIEL SAPUTRA & 2 & 3 & 2 & 3 & 2 & 2 & 2 & 2 & 2 & 2 \\
\hline 89 & ZAKIAADAYANI & 1 & 3 & 2 & 1 & 1 & 2 & 2 & 2 & 2 & 2 \\
\hline 90 & ANGGA RIZKI PRANATA & 2 & 3 & 2 & 2 & 1 & 2 & 2 & 2 & 2 & 2 \\
\hline 91 & MRAIHAN & 3 & 4 & 3 & 3 & 2 & 2 & 1 & 1 & 2 & 1 \\
\hline 92 & PUTRI ANISAH & 2 & 2 & 3 & 3 & 2 & 2 & 2 & 2 & 2 & 2 \\
\hline 93 & MRIZA AHDAZAKI & 1 & 2 & 2 & 2 & 2 & 2 & 2 & 1 & 2 & 2 \\
\hline 94 & MUHAMMAD AMIRULLAH & 2 & 3 & 4 & 2 & 2 & 1 & 1 & 1 & 1 & 1 \\
\hline 95 & RAIFAL ZUL IKBAR & 2 & 3 & 2 & 1 & 2 & 2 & 2 & 1 & 2 & 1 \\
\hline 96 & MUHAMMADRAFAL & 2 & 2 & 3 & 2 & 2 & 1 & 1 & 1 & 2 & 1 \\
\hline 97 & RISKA & 2 & 2 & 3 & 2 & 2 & 1 & 1 & 2 & 2 & 1 \\
\hline 98 & PUTERA JAREZA & 1 & 2 & 2 & 2 & 1 & 1 & 2 & 2 & 2 & 2 \\
\hline 99 & T.NAJI & 1 & 2 & 1 & 1 & 1 & 1 & 1 & 1 & 2 & 1 \\
\hline 00 & & & & & & & & & & & \\
\hline
\end{tabular}

Berikut adalah deskripsi data yang diolah dengan discriminant fishers (lihat Tabel 2) yang banyak datanya adalah 100 untuk setiap variabelnya. Data yang diolah dengan discriminant fishers(tabel.3)

Tabel 3. Pengelompokan data kemampuan siswa berdasarkan nilai pengetahuan agama dan pengetahuan umum

\section{Classification Function Coefficients}

\begin{tabular}{|l|r|r|}
\hline \multirow{2}{*}{} & \multicolumn{2}{|c|}{ Kategori } \\
\cline { 2 - 3 } & $\begin{array}{c}\text { pengetahuan } \\
\text { agama }\end{array}$ & $\begin{array}{c}\text { pengetahuan } \\
\text { umum }\end{array}$ \\
\hline Qr/HD &, 069 &, 039 \\
fiq &,- 236 &,- 322 \\
Aq/Ak &,- 849 &,- 213 \\
SKI & 1,314 & 1,277 \\
B.Arab & 1,862 & 1,308 \\
PPKN &, 804 & 1,223 \\
B.indonesia &, 021 &,- 242 \\
Matematika &, 555 &, 817 \\
IPA &, 994 &, 838 \\
IPS &, 721 &, 744 \\
(Constant) & $-6,128$ & $-6,711$ \\
\hline
\end{tabular}

Fisher's linear discriminant functions

Berdasarkan Tabel 3, diperoleh model untuk pengelompokan kemampuan siswa yaitu sebagai berikut.

Untuk yang pengetahuan agama : 
$0,069 \mathrm{x}_{1}+(-0,236) \mathrm{x}_{2}+(-0,849) \mathrm{x}_{3}+1,314 \mathrm{x}_{4}+$

$1,862 x_{5}+0,804 x_{6}+0,021 x_{7}+0,555 x_{8}+0,994 x_{9}+$ $0,721 \mathrm{x}_{10}=0$

Untuk yang pengetahuan umum :

$0,039 \mathrm{x}_{1}+(-0,322) \mathrm{x}_{2}+(-0,213) \mathrm{x}_{3}+1,277 \mathrm{x}_{4}+$ $1,308 x_{5}+1,223 x_{6}+(-0,242) x_{7}+0,817 x_{8}+0,838 x_{9}$ $+0,744 \mathrm{x}_{10}=0$

Dimana:

$\mathrm{X}_{1}$ : Qur'an hadist, $\mathrm{X}_{2}$ : Fiqih, $\mathrm{X}_{3}$ : Aqidah akhlak, $\mathrm{X}_{4}$ : Sejarah kebudayaan islam, dan sebagainya (lihat tabel 3).

Berikut salah satu contoh dengan data pada subjek kode 3 untuk menentukannya kedalam kelompok tingkat kemampuan siswa berdasarkan pengetahuan agama atau Untuk yang pengetahuan agama :

$0,069(4)+(-0,236)(3)+(-0,849)(3)+1,314(5)+$ $1,862(3)+0,804(3)+0,021(4)+0,555(3)+0,994(2)$

$+0,721(3)=17,489$

Untuk yang pengetahuan umum :

$0,039(4)+(-0,322)(3)+(-0,213)(3)+1,277(5)+$ $1,308(3)+1,223(3)+(-0,242)(4)+0,817(3)+$ $0,838(2)+0,744(3)=17,92$

Dari penjelasan diatas, maka subjek kode 3 termasuk kedalam kelompok yang pengetahuan umum.

\section{KESIMPULAN}

Agama dan pengetahuan umum tidak selamanya berada dalam pertentangan dan ketidaksesuaian. Banyak ilmuan yang berusaha mencarihubungan antara keduanya. Pengetahuan umumdan agama merupakan dua entitas yang berbeda, namun keduanya sama-sama memiliki peranan sangat penting dalam kehidupan manusia. Agama merupakan petunjuk yang dipedomankan melalui aturan dalam kitab suci sedangkan ilmu pengetahuan umum berpijak pada interaksi serta komunikasi yang terbangun dalam masyarakat. Keduanya akan bergandeng pada proses prilaku, moral, etika, stratafikasi sosial dan struktur masyarakat.

Berdasarkan hasil dan pembahasan analisis diskriminan di atas, dapat disimpulkan bahwa ada beberapa variabel independen untuk mengetahui kemampuan siswa, yaitu Alquran Hadist, Fiqih, Aqidah Akhlak, Sejarah Kebudayaan Islam, Bahasa Arab, Ppkn, Bahasa Indonesia, Matematika, IPA, dan IPS. Dari tabel 2 dapat disimpulkan bahwa variabel yang menentukan kemampuan siswa berdasarkan pengeatahuan agama adalah quran hadist, fiqih, sejarah kebudayaan islam, bahasa arab, bahasa indonesia, dan IPA. Sedangkan yang menjadi variabel penentu kemambuan siswa berdasarkan pengetahuan umum adalah aqidah akhlak, Ppkn, Matematika, dan IPS.

Penelitian ini berguna untuk menentukan kemampuan siswa tergolong kedalam pengetahuan agama atau pengetahuan umum. Penentuan kelompok dilakukan dengan cara mensubtitusikan nilai setiap variabelnya kedalam 2 fungsi diskriminan diatas. Nilai terbesar dari kedua fungsi tersebut adalah kelompok dari kemampuan siswa yang diuji. 


\section{DAFTAR PUSTAKA}

Dillon.W.R \& Goldstein.M, (1984), Multivariate Analysis Method and Application, Sons, New york.

Johnson, R, A, and D. W. Wichern, (1988), Applied Multivariate Statistical Analysis, Prentice Hall, Inc, New jersey

Kathleen. M, \& Carmen. A, (2002), SPSS for instutional researchers, Bucknell University.

Kleinbaum, R, A, \& L.L. Kupper, (1978), Applied Multivariate Analysis and Other Multivariate Methods, Ruxbury Press, Massachusects.

Operator, UPI. BAB III Analisis Diskriminan. Diakses melalui http://aresearch.upi.edu/operator/upload/s_mat_0607204_chapter3.pdf. Tanggal akses 15 desember 2017.

Pirhat Abbas. 2010. Hubungan Filsafat, Ilmu, dan Agama. Media Akademika

Simamora, Bilson.Melakukan Analisis Diskriminan.Diakses melalui http://www.bilsonsimamora.com/multivariate/melakukan-analisis-diskriminan/. Tanggal akses 18 desember 2017.

Simamora, Bilson.2005.Analisis Multivariat Pemasaran.Jakarta:Gramedia Pustaka Utama.Diakses_melalui_https://books.google.co.id/books?id=MTrrAB756b8C\&printsec=frontcover

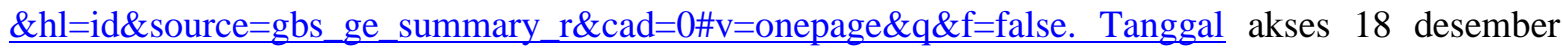
2017.

Umam, Khairul. Diskriminan. Diakses melalui: www.informatika.unsyiah.ac.id/umam/diskriminan.pdf. Tanggal akses 14 desember 2017. 